\title{
Production Performance of Peking Ducks with Feeding of Fermented Yeast Culture Pineapple Peel (Saccharomyces cereviceae)
}

\author{
Bulkaini $^{1 *}$, Djoko Kisworo ${ }^{1}$, Budi Indarsih ${ }^{1}$, I K Sumadi ${ }^{2}$ \\ ${ }^{1}$ Fakultas Peternakan, Universitas Mataram, Mataram, Indonesia; \\ ${ }^{2}$ Fakultas Peternakan, Universitas Udayana, Denpasar, Indonesia;
}

\begin{abstract}
Article History
Received : September $15^{\text {th }}, 2021$

Revised : September $30^{\text {th }}, 2021$

Accepted : October $15^{\text {th }}, 2021$

Published : October 27 , 2021

*Corresponding Author:

Bulkaini,

Fakultas Peternakan, Universitas

Mataram, Mataram, Indonesia;

Email: b kaini@yahoo.com
\end{abstract}

\begin{abstract}
Poultry production performance is reflected by body weight gain, ration conversion and carcass percentage. This study was conducted with the aim of knowing the optimum level of use of fermented pineapple peel in the ration on production performance and carcass percentage of male Peking ducks. The research material was male Peking duck aged 3 weeks with initial body weight of $343.90 \pm 0.90$ g. 240 male Peking ducks were placed randomly in battery cages based on a Completely Randomized Design with 6 treatments and 5 replications, namely $\mathrm{P} 0=$ ration without fermented pineapple peel (FPP); P1=the ration contains 5\% FPP; $\mathrm{P} 2=$ ration contains $10 \% \mathrm{FPP} ; \mathrm{P} 3=$ the ration contains $15 \% \mathrm{FPP} ; \mathrm{P} 4=$ ration contains 20\% FPP and P5=the ration contains 25\% FPP. Based on One way ANOVA analysis and Duncan's test, it was found that the use of fermented pineapple peel $10 \%$ significantly $(\mathrm{P}<0.05)$ increased the final body weight $(1.693 \mathrm{~g} / \mathrm{head})$, body weight gain $(1.350 \mathrm{~g} / \mathrm{head})$, and carcass percentage $(55.25 \%)$. From the results of the study, it can be concluded that the optimum level of use of fermented pineapple peel with yeast culture on body weight gain, slaughter weight, carcass weight and carcass percentage, respectively: $8.80 \% ; 8.40 \% ; 7.25 \%$ and $9.50 \%$.
\end{abstract}

Keywords: Fermentation, production performance, yeast culture

\section{Pendahuluan}

Itik peking adalah salah satu bangsabangsa itik yang termasuk dalam golongan tipe pedaging (Tanwiriah at al., 2018). Itik peking merupakan itik tipe pedaging yang termasuk dalam kategori unggas air yang cocok untuk dikembangbiakkan di Indonesia dengan sistem pemeliharaan intensif dan penambahan kolam atau tampa kolam di dalam area pemeliharaan. Indikator kinerja produksi unggas terditi atas: pertambahan bobot badan, konversi ransum dan persentase karkas (Bidura et al., 2018). Selanjutnya dikatakan bahwa konversi ransum dapat digunakan sebagai tolak ukur efisiensi pakan yang diberikan kepada itik untuk menghasilkan bobot tubuh, semakin rendah nilai konversi ransum maka pertumbuhan itik semakin baik dan maksimal.

Pertambahan bobot badan, konsumsi ransum dan konversi pakan merupakan indikator untuk mengevaluasi baik tidaknya kinerja itik peking sebagai penghasil karkas (Tanwiriah et al., 2018). Kualitas karkas dipengaruhi oleh dua faktor yaitu: (1) Faktor sebelum pemotongan antara lain genetik, spesies, bangsa, tipe ternak, jenis kelamin, umur potong, pakan termasuk bahan aditif (hormon, antinbiotika dan probiotik) dan (2) Faktor setelah pemotongan antara lain: metode pelayuan, stimulasi listrik, metode pemasakan, $\mathrm{pH}$ karkas, bahan tambahan termasuk enzim pengempuk daging, lemak inramuskular atau marbling dan lokasi otot (Soeparno, 2015). Dijelaskan juga bahwa kualitas karkas ditentukan oleh bobot karkas, persentase karkas, jumlah daging yang dihasilkan dan kualitas daging dari karkas. Bobot karkas dipengaruhi oleh bobot hidup, konsumsi pakan, bobot non karkas seperti bulu dan organ dalam (Bidura et al., 2018).

Itik peking yang diberi pakan wafer ransum komplit mengandung limbah kulit kopi pada level $2,5 \%$ pada umur potong 8 minggu mempunyai bobot potong $1.866,7 \mathrm{~g}$, bobot karkas 1.133 g dengan persentase karkas $61.60 \%$ (Daud et al., 2016). Persentase karkas dipengaruhi oleh bobot badan, keadaan nutrisi pakan, jenis kelamin, kecepatan tumbuh dan umur pemotongan (Soeparno, 2015). Persentase karkas merupakan perbandingan antara bobot karkas dengan bobot hidup yang sering digunakan untuk memprediksi jumlah daging 
pada unggas. Matitaputty dan Suryana (2014) menyatakan itik peking jantan umur 12 minggu mempunyai persentase karkas sebesar $60,6 \%$ lebih rendah dengan persentase karkas itik persilangan antara itik peking jantan dengan muscopy (61,8\%). Data kinerja produksi itik peking jantan yang diberikan kulit nanas terfermentasi sangat diperlukan untuk melihat respon itik peking jantan yang diberi pakan dengan limbah kulit nanas terfermentasi.

Bidura et al. (2012), menyatakan bahwa fermentasi merupakan suatu proses terjadinya perubahan kimia pada suatu substrat organik melalui aktivitas enzim yang dihasilkan oleh mikroorganisme. Fermentasi oleh mikroba mampu mengubah makromolekul kompleks menjadi molekul sederhana yang mudah dicerna oleh unggas dan tidak menghasilkan senyawa kimia beracun (Ariana et al., 2018). Dalam fermentasi limbah kulit nanas dapat digunakan inokulum padat seperti ragi tape atau cair seperti Aspergillus niger 2\%, Actinobacillus sp.ML-8, Laktobasilus 5\%). Ragi tape (Saccharomyces cereviceae) adalah starter untuk membuat tape ketan atau tape singkong. Di dalam ragi tape terdapat mikroorganisme yang dapat mengubah karbohidrat (pati) menjadi gula sederhana (glukosa) yang selanjutnya diubah lagi menjadi alkohol. Beberapa jenis mikroorganisme yang terdapat dalam ragi tape adalah Chlamydomucor oryzae, Rhizopus oryzae, Mucor sp., Candida sp., Saccharomyces cerevisiae, dan Saccharomyces verdomanii (Aries, 2017). Kebaruan dalam penelitian ini adalah ditemukan level optimum penggunaan kulit nanas terfermentasi ragi tape terhadap kinerja produksi itik peking jantan. Berdasarkan uraian di atas dilakukan penelitian dengan judul "Kinerja produksi itik peking jantan dengan pemberian pakan kulit nanas fermentasi ragi tape (Saccahomyces cereviceae)".

\section{Bahan dan Metode}

\section{Materi penelitian}

Materi yang digunakan dalam penelitian adalah itik peking jantan umur 3 minggu dengan bobot badan awal $343,90 \pm 0,90 \mathrm{~g}$ sebanyak 240 ekor. Pakan itik itik umur 15 hari-8 minggu diberikan ransum yang disusun dengan bahanbahan: pakan konsentrat ternak babi fase pertumbuhan (152 HI-GRO), jagung kuning giling, bekatul dan kulit nanas terfermentasi.
Standar kandungan protein kasar $(\mathrm{CP})$ dan energi metabolisme (ME) pakan itik mengacu standar NRC=National Research Council (1994) yaitu ME $2900 \mathrm{kkal} / \mathrm{kg}$ dengan CP 16\%, mineral (Ca:0,60\%; Pav:0,35\%; Met+Cys:0,60\% dan Lysine $0.90 \%$ ). Kandang penelitian untuk itik umur 3-8 minggu berupa kandang sistem "battery colony" dengan ukuran $200 \mathrm{~cm}$ x $60 \mathrm{~cm}$ x $50 \mathrm{~cm}$ sebanyak 30 petak dan dilengkapi dengan tempat pakan dari pipa paralon ukuran 3 inci dan tempat air minum terbuat dari botol aqua ukuran 1 liter yang diberi lubang pada bagian tengahnya.

\section{Tahapan penelitian}

Penelitian diawali dengan proses fermentasi kulit nanas. Fermentasi kulit nanas dilakukan dengan metode fakultatif anaerob (Bidura et al.,2012), dengan prosedur sebagai berikut: (1) Kulit nanas terlebih dahulu dibersihkan, dicincang, dijemur di bawah matahari, kemudian digiling, sehingga menjadi tepung (Nurhayati dan Berliana, 2014); (2) Tepung kulit nanas dikukus selama 30 menit agar steril dari berbagai macam mikrobia seperti jamur dan bakteri lainnya yang dapat mengganggu proses fermentasi; (3) Setelah dingin, ditambahkan ragi tape dengan persentase yang berbeda yaitu $0 \%(\mathrm{P} 0), 0,5 \%(\mathrm{P} 1), 1 \%(\mathrm{P} 2)$ dan 1,5\% (P3) dari berat tepung kulit nanas; (4) Membuat larutan molases dengan konsentrasi 25\% (200 ml molases:800 ml air steril); (5) Masing-masing perlakuan dilakukan penyemprotan dengan larutan molases yang sudah disiapkan sambil diaduk secara merata sampai terbentuk kepalan tepung kulit nanas yang tidak pecah; (6) Hasil penyemprotan tepung kulit nanas dimasukkan dalam wadah berupa ember plastik yang tertutup longgar untuk mendapatkan kondisi anaerob fakultatif dan diinkubasi pada suhu ruang dan tidak kena sinar matahari selama 3-4 hari; (7) setelah masa inkubasi selesai, hasil fermentasi dijemur dibawah sinar matahari hingga kering. Hasil fermentasi yang terbaik yaitu fermentasi menggunakan $1 \%$ ragi tape yang digunakan sebagai bahan penyusun ransum itik peking jantan.

\section{Ransum Penelitian}

Susunan ransum yang digunakan dalam penelitian disajikan pada Tabel 1 . 
Tabel 1. Komposisi Ransum dan Kandungan Nutrisi Berdasarkan Perhitungan

\begin{tabular}{lccccccc}
\hline \multirow{2}{*}{ Komposisi Bahan (\%) } & \multicolumn{7}{c}{ Perlakuan } \\
\cline { 2 - 8 } & $\mathrm{R} 0$ & $\mathrm{R} 1$ & $\mathrm{R} 2$ & $\mathrm{R} 3$ & $\mathrm{R} 4$ & $\mathrm{R} 5$ & \\
\hline Konsentrat komersial & 21 & 21 & 23 & 24 & 24 & 25 & \\
Jagung Giling & 55 & 48 & 48 & 42 & 39 & 37 & \\
Bekatul & 24 & 26 & 19 & 19 & 17 & 13 & \\
Tepung kulit nanas & 0 & 5 & 10 & 15 & 20 & 25 & \\
Minyak kelapa & & & $(2)$ & $(3,5)$ & $(4,5)$ & $(5)$ & \\
\hline Jumlah & 100 & 100 & 100 & 100 & 100 & 100 & \\
\hline Kandungan Nutrisi Ransum & & & & & & $(1)$ \\
\hline ME (Kkal/Kg) & 2929.70 & 2908.92 & 2910.06 & 2910.76 & 2905.48 & 2902.20 & 2900 \\
CP (\%) & 16.38 & 16.01 & 16.16 & 16,27 & 16.09 & 16.02 & 16 \\
SK (\%) & 4.18 & 4.42 & 4.68 & 5.12 & 5.48 & 4.09 & 10 \\
EE (\%) & 4,619 & 6.31 & 5.90 & 5.98 & 5.96 & 4.37 & 8 \\
Ca (\%) & 0.66 & 0.65 & 0.71 & 0.74 & 0.74 & 0.82 & 0,60 \\
Pav (\%) & 0.86 & 0.81 & 0.76 & 0.77 & 0.75 & 0.77 & 0,35 \\
Metyonine+ Cys (\%) & 0.27 & 0.28 & 0.27 & 0.27 & 0.27 & 0.27 & 0,60 \\
Lysine (\%) & 0.32 & 0.31 & 0.28 & 0.28 & 0.28 & 0.26 & 0,90 \\
\hline
\end{tabular}

Keterangan : Persentase minyak kelapa bersifat mencukupi kandungan ME

$$
\text { (1) = Standar NRC (1994) }
$$

R0 : Konsentrat komersial $21 \%+55 \%$ jagung giling $+24 \%$ bekatul $+0 \%$ kulit nanas ter fermentasi

R1 : Konsentrat komersial $21 \%+48 \%$ jagung giling $+26 \%$ bekatul $+5 \%$ kulit nanas terfermentasi.

R2 : Konsentrat komersial $23 \%+48 \%$ jagung giling $+19 \%$ bekatul $+10 \%$ kulit nanas terfermentasi.

R3 : Konsentrat komersial $24 \%+42 \%$ jagung giling $+19 \%$ bekatul $+15 \%$ kulit nanas terfermentasi.

R4 : Konsentrat komersial $24 \%+39 \%$ jagung giling $+17 \%$ bekatul $+20 \%$ kulit nanas terfermentasi.

R5 : Konsentrat komersial $25 \%+37 \%$ jagung giling $+13 \%$ bekatul $+25 \%$ kulit nanas terfermentasi.

\section{Variabel penelitian}

a. Bobot badan awal : bobot awal yang dimaksudkan adalah bobot awal itik umur 2 minggu.

b. Bobot badan akhir: Penimbangan dilakukan setelah itik berumur 8 minngu.

c. Pertambahan bobot badan (pbb). Pertambahan bobot badan merupakan hasil pengurangan bobot badan akhir dengan bobot badan awal.

d. Konsumsi ransum. Konsumsi ransum diukur setiap hari, yaitu selisih antara jumlah ransum yang diberikan dengan sisa ransum. Pada akhir penelitian dihitung konsumsi ransum itik per ekor selama 6 minggu.

e. Feed Conversion Rasio (FCR). FCR diperoleh dengan membagi konsumsi ransum dengan pertambahan berat badan dalam satuan waktu yang sama (Sumadi, 2018).

f. Persentase karkas Perbandingan antara berat karkas dengan bobot potong dikalikan $100 \%$.

\section{Rancangan percobaan}

Penelitian dilakukan dengan menggunakan Rancangan Acak Lengkap (RAL) yang terdiri atas 6 perlakuan dengan 5 ulangan, sehingga terdapat 30 unit percobaan. Masingmasing unit percobaan menggunakan 8 ekor itik peking jantan, sehingga jumlah itik yang digunakan sebanyak 6 × 5 × $8=240$ ekor. Kreteria itik yang digunakan dalam penelitian ini adalah itik peking jantan umur 2 minggu dengan bobot baban awal yang homogen yaitu 350,20-359,65 g yang diperoleh dari 400 ekor DOD yang pelihara selama 2 minggu. Berdasarkan rancangan penelitian yang digunakan, maka perlakuan penelitian dapat disusun sebagai berikut:

P0 : Ransum tanpa kulit nanas terfermentasi sebagai control

P1 : Ransum mengandung 5\% kulit nanas terfermentasi. 
P2 : Ransum mengandung 10\% kulit nanas terfermentasi.

P3 : Ransum mengandung 15\% kulit nanas terfermentasi.

P4 : Ransum mengandung 20\% kulit nanas terfermentasi.

P5 : Ransum mengandung 25\% kulit nanas terfermentasi.

\section{Analisis data}

Data hasil penelitian dianalisis dengan One Way Anova berdasarkan Rancangan Acak Lengkap pola searah (Steel and Torrie, 2015), dengan model matematika :

Dimana :

$$
\mathrm{Yij}=\mu+\mathrm{Ai}+\mathrm{Eij}
$$

Yij = Hasil pengamatan masing-masing parameter

$\mu=$ Rata-rata (nilai tengah)

$\mathrm{Ai}=$ Pengaruh level pemberian kulit nanas

Eij $=$ Error pengaruh level pemberian kult nanas.
Analisis data dilanjutkan dengan uji Duncan Multiple Range Test (DMRT) pada tingkat kepercayaan 5\% menggunakan program SPSS versi 16.

\section{Hasil dan Pembahasan}

\section{Performa produksi itik peking jantan}

Hasil penelitian tentang pengaruh pemberian kulit nanas terfermentasi terhadap performa produksi itik peking jantan disajikan pada Tabel 2. Hasil analisis One-way anova menunjukkan bahwa pemberian kulit nanas terfermentasi berpengaruh nyata $(\mathrm{P}<0,05)$ terhadap bobot badan akhir (BB Akhir), pertambahan bobot badan (PBB) dan konsumsi ransum (KR), sedangkan terhadap feed conversion ratio (FCR) dan bobot badan awal (BB awal) tidak berpengaruh nyata $(\mathrm{P}>0,05)$.

Tabel 2. Performa Produksi Itik Peking Jantan Umur 3-8 Minggu dengan Pemberian Pakan Kulit Nanas Fermentasi

\begin{tabular}{|c|c|c|c|c|c|c|c|}
\hline \multirow{2}{*}{ Variabel } & \multicolumn{6}{|c|}{ Level pemberian kulit nanas fermentasi } & \multirow{2}{*}{ SEM } \\
\hline & P0 & $\mathrm{P} 1$ & $\mathrm{P} 2$ & P3 & P4 & P5 & \\
\hline BB awal (g) & $343,50^{a}$ & $345,45^{a}$ & $343,08^{a}$ & $343,20 \mathrm{a}$ & $344,43^{a}$ & $343,73^{a}$ & 3,40 \\
\hline $\begin{array}{l}\text { BB akhir } \\
\text { (g/ekor/6 minggu ) }\end{array}$ & $1.565,50^{\mathrm{a}}$ & $1.644,50^{\mathrm{b}}$ & $1693,25^{b}$ & $1544,00^{a}$ & $1.544,75^{\mathrm{a}}$ & $1.560,75^{\mathrm{a}}$ & 20,75 \\
\hline $\begin{array}{l}\mathrm{PBB} \text { (g/ekor/ } 6 \\
\text { minggu) }\end{array}$ & $1.222,00^{\mathrm{a}}$ & $1.299,05^{b}$ & $1.350,18^{b}$ & $1.200,80^{\mathrm{a}}$ & $1.200,33^{a}$ & $1.217,03^{\mathrm{a}}$ & 18,44 \\
\hline $\begin{array}{l}\mathrm{KR} \text { (g/ekor/ } 6 \\
\text { minggu) }\end{array}$ & $5.742,63^{a}$ & $6.032,40^{\mathrm{b}}$ & $6.092,72^{b}$ & $5.855,83^{a b}$ & $5.862,44^{\mathrm{ab}}$ & $5.672,67^{\circ}$ & 86,80 \\
\hline FCR & $4,70 \mathrm{a}$ & $4,64 a$ & $4,51^{a}$ & $4,88^{a}$ & $4,88^{a}$ & $4,66^{a}$ & 0,11 \\
\hline
\end{tabular}

Keterangan:

1. $\quad \mathrm{P} 0=$ Ransum tanpa kulit nanas fermentasi sebagai kontrol; $\mathrm{P} 1=$ Ransum mengandung $5 \%$ kulit nanas terfermentasi; P2 = Ransum mengandung 10\% kulit nanas terfermentasi; P3 = Ransum mengandung $15 \%$ kulit nanas terfermentasi; $\mathrm{P} 4=$ Ransum mengandung 20\% kulit nanas terfermentasi; $\mathrm{P} 5=$ Ransum mengandung $25 \%$ kulit nanas terfermentasi; $\mathrm{BB}$ awal $=$ Bobot badan awal; $\mathrm{BB}$ akhir $=$ Bobot badan akhir; $\mathrm{PBB}=$ Pertambahan bobot badan; $\mathrm{KR}=$ Konsumsi ransum $\mathrm{FCR}=$ Feed conversion ratio.

2. $\mathrm{SEM}=$ Standar Error of the Treatmen Means.

3. Hurup yang berbeda pada baris yang sama menunjukkan perbedaan yang nyata $(\mathrm{P}<0,05)$.

PBB itik peking jantan paling tinggi terjadi pada $\mathrm{P} 2(1.350,18 \mathrm{~g})$ dan berbeda nyata $(\mathrm{P}<0,05)$ dengan P0 (1.222,00 g); P3 $(1.222,80$ g); P4 (1.200,33 g) dan P5 (1.217,03 g). PBB itik peking jantan mengalami peningkatan sampai pada perlakuan $\mathrm{P} 2$ dengan rata-rata peningkatan sebesar 5,24\%, selanjutnya PBB itik peking jantan pada perlakuan P3 sampai perlakuan P5 mengalami penurunan sebesar $0,73 \%$.
Dari Tabel 2 terlihat bahwa BB akhir dan PBB itik peking jantan yang paling tinggi terjadi pada P2. Hal ini disebabkan karena pada P2 jika dilihat dari konsumsi ransum (6.092,72 g/ekor/6 minggu) lebih tinggi dibandingkan dengan perlakuan yang lain. Hasil penelitian ini sesuai dengan pendapat Daud et al. (2017) yang menyatakan bahwa BB akhir dan PBB ternak senantiasa berbanding lurus dengan konsumsi ransum, semakin besar bobot badan semakin 
banyak jumlah konsumsi ransumnya. Dipertegas lagi oleh Sumadi (2018) yang menyatakan bahwa tingkat konsumsi ransum erat hubungannya dengan pertumbuhan, semakin banyak ransum yang dikonsumsi semakin tinggi pertambahan bobot badan yang dihasilkan. Salah satu faktor yang menyebabkan bahwa pada perlakuan P2 bisa memberikan pertumbuhan yang tinggi karena pemberian pakan yang mengandung $10 \%$ kulit nanas terfermentasi dapat meningkatkan kinerja produksi itik secara signifikan. Hal ini senada dengan pendapat Mudita et al.(2019), bahwa pemberian Saccharomyces cereviceae pada ransum dapat menurunkan populasi bakteri pathogen dalam saluran pencernaan, tetapi sebaliknya dapat memacu pertumbuhan kelompok bakteri aerob dan anaerob yang menguntungkan dalam usus itik sehingga pencernaan bisa sempurna yang pada akhirnya dapat memberikan pertumbuhan yang sempurna juga.

PBB itik peking jantan yang dipelihara selama 6 minggu dengan penambahan kulit nanas terfermentasi $10 \%$ memberikan PBB sebesar 1.350,18 g/ekor/6 minggu atau 32,147 g/ekor/hari lebih tinggi dibandingkan dengah hasil penelitian Sukirmansyah et al., 2016), yang melaporkan bahwa itik peking jantan yang diberikan pakan komersial BR-1 pada umur 6 minggu mempunyai PBB sebesar 1.171,04 g/ekor atau 27,88 g/ekor/hari dengan konversi pakan sebesar 3,18. Itik pedaging hasil persilangan itik lokal dengan itik peking dengan ransum komersial BUS 602-cruble mempunyai PBB sebesar 12,04 g/ekor/hari dengan konversi ransum 2,66.

Peningkatan konsumsi ransum dapat pula disebabkan karena pakan hasil fermentasi dengan menggunakan probiotik khamir Saccharomyces cereviceae dapat mengubah gizi bahan pakan menjadi lebih baik sehingga dapat meningkatkan palatabilitas pakan yang pada akhirnya dapat menyebabkan konsumsi pakan meningkat (Bidura, 2012). Hal ini juga sesuai dengan pendapat Daud et al. (2013) yang menyatakan bahwa konsumsi ransum dan konsumsi bahan lainnya sangat dipengaruhi oleh palatabilitas ransum, jenis, dan komposisi penggunaan bahan pakan dalam formulasi ransum itik peking. Bidura et al. (2019) menyatakan bahwa dalam kulit nanas fermentasi dengan kultur ragi tape mengandung probiotik khamir Saccharomyces cereviceae. Lebih lanjut dijelas-kan bahwa probiotik adalah mikroba hidup yang diberikan sebagai suplemen makanan dengan tujuan memperbaiki kesehatan dan perkembagan mikroba. Menurut Mudita et al. (2019), probiotik adalah imbuhan pakan berbentuk mikroba hidup yang menguntungkan dan mempengaruhi induk semang melalui perbaikan keseimbangan mikroorganisme dalam saluran pencernaan ternak, memberikan keuntungan pada inang melalui seleksi yang selektif pada pertumbuhan dan aktivitas dari satu atau sejumlah bakteri yang terdapat di dalam kolon ternak unggas.

Respon itik peking jantan terhadap pemberian kulit nanas yang difermentasi dengan ragi tape (Saccharomyces cereviceae) menunjukkan respon yang baik, hal ini terbukti dari nilai FRC yang diberikan oleh semua perlakuan berkisar 4,5-4,88 seperti yang terlihat pada Tabel 2. Tabel 2 menunjukkan bahwa pada P2 mempunyai nilai FCR yang paling rendah yaitu sebesar 4,51. Hal ini disebabkan karena laju PBB sejalan dengan peningkatan jumlah pakan yang dikonsumsi atau pakan yang dikonsumsi dapat dimaksimalkan untuk proses pertumbuhan sehingga berpengaruh terhadap PBB itik peking jantan. Pada P0; P1; P3; P4 dan P5 memiliki nilai FCR yang relatif lebih tinggi. Hal ini disebabkan karena peningkatan jumlah pakan yang dikonsumsi tidak diimbangi oleh PBB itik peking jantan. Bidura (2012) dan Sumadi (2018) menyatakan bahwa semakin kecil nilai FCR pakan semakin baik mutu ransum. Bidura et al. (2012) menya-takan bahwa semakin kecil nilai FCR yaitu mendekati angka 1,75-2,00 berarti kualitas pakan semakin baik. Selanjutnya dikatakan bahwa FCR merupakan salah satu indikator yang dapat memberikan gambaran tentang tingkat efisiensi penggunaan ransum.

Berdasarkan hasil analisis SPSS (Statistical Product and Service Solutions) for windows diperoleh persamaan kuadratik untuk menentukan level optimum penggunaan kulit nanas terfermentasi terhadap bobot akhir itik peking jantan yaitu: $Y=0,0001596+6,355 \mathrm{x}-$ $0,362 x^{2}$, sehingga diperoleh level optimum penggunanan kulit nanas terfermentasi yang dapat memberikan bobot akhir itik peking jantan yang paling tinggi sebesar $8,77 \%$. Selanjutnya level optimum penggunaan kulit nanas terfermentasi terhadap pertambahan bobot baban dapat dihitung dengan menggunakan persamaan kuadratik yaitu: $Y=0,0001252+6,386 \mathrm{x}-0,363 \mathrm{x}^{2}$, sehingga diperoleh level optimum penggunanan kulit nanas ter-fermentasi yang dapat menghasilkan pertambahan bobot badan yang paling tinggi yaitu sebesar $8,80 \%$. 


\section{Persentase Karkas Itik Peking Jantan}

Hasil penelitian tentang pengaruh pemberian kulit nanas terfermentasi terhadap kualitas karkas itik peking jantan disajikan pada Tabel 3.

Tabel 3. Persentase Karkas Itik Peking Jantan Umur Potong 8 Minggu dengan Pemberian Pakan Kulit Nanas Fermentasi

\begin{tabular}{lccccccc}
\hline \multirow{2}{*}{$\begin{array}{l}\text { Karkas dan } \\
\text { non karkas }\end{array}$} & P0 & P1 & P2 & P3 & P4 & P5 & \multirow{2}{*}{ SEM } \\
\hline BP $(\mathrm{g})$ & $1.646^{\mathrm{a}}$ & $1.682^{\mathrm{a}}$ & $1.712^{\mathrm{b}}$ & $1.612^{\mathrm{ac}}$ & $1.654^{\mathrm{ac}}$ & $1.578^{\mathrm{d}}$ & 25,50 \\
BK $(\mathrm{g})$ & $904^{\mathrm{a}}$ & $910^{\mathrm{a}}$ & $946^{\mathrm{b}}$ & $868^{\mathrm{c}}$ & $886^{\mathrm{c}}$ & $822^{\mathrm{d}}$ & 17,97 \\
Karkas $(\%)$ & $54,94^{\mathrm{a}}$ & $54,11^{\mathrm{a}}$ & $55,25^{\mathrm{a}}$ & $53,85^{\mathrm{a}}$ & $53,61^{\mathrm{ab}}$ & $52,07^{\mathrm{b}}$ & 0,78 \\
\hline
\end{tabular}

Keterangan:

1. $\mathrm{P} 0=$ Ransum tanpa kulit nanas fermentasi sebagai kontrol; $\mathrm{P} 1=$ Ransum mengandung $5 \%$ kulit nanas terfermentasi; P2 = Ransum mengandung 10\% kulit nanas terfermentasi; P3 = Ransum mengandung $15 \%$ kulit nanas terfermentasi; P4 = Ransum mengandung 20\% kulit nanas fermentasi; P5 = Ransum mengandung 25\% kulit nanas terfermentasi; $\mathrm{BP}=$ Bobot potong; $\mathrm{BK}=$ Bobot karkas

2. $\mathrm{SEM}=$ Standar Error of the Treatmen Means.

3. Hurup yang berbeda pada baris yang sama menunjukkan perbedaan yang nyata $(\mathrm{P}<0,05)$.

Hasil analisis One-way anova menunjukkan bahwa pemberian kulit nanas terfermentasi berpengaruh nyata $(\mathrm{P}<0,05)$ terhadap bobot potong, bobot karkas, dan persentase karkas. Hasil penelitian (Tabel 3) menunjukan bahwa bobot potong itik peking jantan pada umur potong 8 minggu berkisar $1.578-1.712 \mathrm{~g}$. Bobot potong pada P2 (1.712 g) lebih tinggi dan berbeda nyata $(\mathrm{P}<0,05)$ dengan bobot potong pada P0 (1.646 g); P1 (1.682 g); P3 (1.612 g); P4 (1.654 g) dan P5 (1.578 g). Hasil analisis statistik menunjukkan bahwa pemberian kulit nanas terfermentasi dalam ransum pada level 10\% (P2) dapat menghasilkan bobot potong itik peking jantan yang paling tinggi diantara perlakuan.

Bobot karkas itik peking jantan umur potong 8 minggu pada P2 (946 g) lebih tinggi dan berbeda nyata $(\mathrm{P}<0,05)$ dengan $\mathrm{P} 0(904 \mathrm{~g}) ; \mathrm{P} 1$ (910 g); P3 (868 g); P4 (886 g) dan P5 (822 g). Hasil penelitian menunjukkan bahwa pemberian kulit nanas terfermentasi pada level 10\% (P2) dapat menghasilkan bobot karkas yang lebih tinggi dibandingkan dengan perlakuan yang lain.

Hasil uji Duncan menunjukkan bahwa persentase karkas itik peking jantan umur potong 8 minggu pada $\mathrm{P} 2(55,25 \%)$ secara tidak nyata $(\mathrm{P}>0,05)$ lebih tinggi dibandingkan dengan $\mathrm{P} 0$ $(54,94 \%) ; \quad P 1 \quad(54,11 \%) ; \quad$ P3 (53,85\%); P4 $(53,61 \%)$ dan berbeda nyata $(\mathrm{P}<0,05)$ dengan $\mathrm{P} 5$ $(52,07 \%)$. Hasil penelitian menunjukkan bah-wa pemberian kulit nanas terfermentasi pada level $10 \%$ (P2) dapat menghasilkan persentase karkas yang lebih tinggi dibandingkan dengan perlakuan yang lain.

Penambahan kulit nanas terfermentasi pada level $10 \%$ dalam ransum dapat memberikan bobot potong (BP); bobot karkas (BK) dan persentase karkas itik peking jantan yang paling tinggi dibandingkan dengan tanpa penambahan kulit nanas terfermentasi; level penambahan 5\%; $15 \%$; $20 \%$ dan 25\%. Hal ini tercermin dari BP, BK dan persentase karkas yang lebih tinggi dibandingkan dengan perlakuan lainnya seperti terlihat pada Tabel 3 .

Hasil penelitian ini membuktikan bahwa penggunaan kulit nanas terfermentasi yang mengandung probiotik khamir Saccharomyces cereviceae dapat meningkatkan kinerja produksi itik secara signifikan. Hasil penelitian ini sejalan dengan hasil penelitian Nurhayati (2013), dimana penggunaan $10 \%$ tepung kulit nanas yang difermentasi dengan Lactobacillus $s p$. sebanyak $3 \mathrm{ml} / \mathrm{kg}$ dalam bahan dapat mempertahankan performa produksi broiler. Nunes et al. (2012) menyatakan penggunaan probiotik dalam ransum mendapatkan hasil yang positif yaitu meningkatkan persentase karkas.

Dari Tabel 3. terlihat bahwa pemberian kulit nanas terfermentasi pada level $10 \%$ memberikan BP (1.712 g/ekor) dan persentase karkas $(55,25 \%)$ yang paling tinggi dibandingkan dengan perlakuan yang lain. Hal ini disebabkan karena penambahan BP sejalan dengan penambahan BK dan memiliki konsumsi ransum yang paling tinggi. BP itik peking jantan sebesar 1.712 g/ekor dengan karkas sebesar 
$55,25 \%$ yang diperoleh dalam penelitian ini lebih tinggi dibandingkan dengan BP dan persentase karkas itik peking jantan yang diberi ransum terfermentasi probiotik $12,5 \mathrm{ml} /$ liter air pada umur potong 8 minggu yaitu mempunyai $\mathrm{BP}$ sebesar 903,75 g/ekor dengan persentase karkas 54,06\% (Sukirmansyah et al., 2016). Daud et al. (2018), melaporkan bahwa itik peking yang diberi ransum dengan substitusi kulit pisang fermentasi $8 \%$, pada umur potong 8 minggu mempunyai BP sebesar $1.366,04 \mathrm{~g}$. Daud et al. (2015) memperlihatkan BP itik peking umur 8 minggu yang diberi hijauan kangkung fermentasi probiotik berkisar antara $1.641-2.150 \mathrm{~g}$.

Hasil penelitian ini bebeda juga dengan hasil penelitian Prasetyo et al. (2017) yaitu itik peking jantan yang diberi pakan basah dengan penambahan probiotik $9 \mathrm{~g} / \mathrm{kg}$ umur potong 8 minggu mempunyai BP 1.325 g/ekor dengan persentase karkas $61,51 \%$. Itik peking jantan dengan pemberian ransum yang disubstitusi roti afkir sebanyak $30 \%$ pada umur potong 8 minggu mempunyai $\mathrm{BK}$ sebesar 536,25 g/ekor dengan persentase karkas 55,09\% (Bellabur, 2014).

Berdasarkan hasil analisis SPSS (Statistical Product and Service Solutions) for windows diperoleh persamaan kuadratik untuk menentukan level optimum penggunaan kulit nanas terfermentasi terhadap bobot potong peking jantan yaitu: $\mathrm{Y}=0,0001654+6,149 \mathrm{x}-$ $0,366 x^{2}$, sehingga diperoleh level optimum penggunanan kulit nanas terfermentasi yang dapat meningkatkan bobot potong sebesar $8,40 \%$. Level optimum penggunaan kulit nanas terfermentasi terhadap bobot karkas dapat dihitung dengan menggunakan persamaan kuadratik yaitu: $Y=904,214+4,366 x-0,301 x^{2}$ sehingga diperoleh level optimum penggunanan kulit nanas terfermentasi yang dapat meningkatkan bobot karkas sebesar 7,25\%. Selanjutnya Level optimum penggunaan kulit nanas terfermentasi terhadap persentase karkas dapat dihitung dengan menggunakan persamaan kuadratik yaitu: $\quad \mathrm{Y}=53.652+0,209 \mathrm{x}-0,011 \mathrm{x}^{2}$ sehingga diperoleh level optimum penggunanan kulit nanas terfermentasi yang dapat meningkatkan persertase karkas sebesar 9,50\%.

\section{Kesimpulan}

Level optimum penggunaan kulit nanas terfermentasi ragi tape terhadap pertambahan bobot badan, bobot potong, bobot karkas dan persentase karkas masing-masing berturut-turut: $8,80 \% ; 8,40 \% ; 7,25 \%$ dan $9,50 \%$. Penggunaan kulit nanas terfermentasi $10 \%$ secara nyata $(\mathrm{P}<0,05)$ meningkatkan bobot badan akhir $(1.693$ g/ekor), pertambahan bobot badan (1.350 g/ekor), dan persentase karkas $(55,25 \%)$ itik peking jantan.

\section{Ucapan terima kasih}

Peneliti mengucapkan terima kasih kepada Rektor Universitas Mataram yang telah memberikan dana penelitian yang bersumber dari dana Badan Layanan Umum Universitas Mataram serta semua pihak yang telah membantu baik moril maupun materil.

\section{References}

Ariana, I.N.T. G. A. M. Kristina Dewi, M. Wirapartha, I. W. Wijana, I. K. Anom Wiyana and N. W. Sitiari (2018). Production and Income Over Feed and Chick Cost (IOFCC) of Broiler Chicken Which Feed The Fermented Dragon Fruit Skin Ration (Hylocereus Polyrhizus). Jurnal Ekonomi dan Bisnis Jagaditha. 5(2): 92-96.

Aries, E.J. (2017). Kandungan Mineral (Ca Dan $\mathrm{Mg}$ ) Pada Dedak Padi Yang Difermentasi Menggunakan Ragi Tape (Saccharomyces cerevisiae). Laporan Penelitian. Jurusan Ilmu Peternakan Fakultas Sains Dan Teknologi Universitas Islam Negeri (UIN) Alauddin Makassar.

Bellabur, Y. (2014). Pemanfaatan Roti Afkir Dalam Ransum Terhadap Karkas Itik Peking Umur 1-8 Minggu. Laporan Penelitian. Program Studi Peternakan. Fakultas Pertanian Universitas Sumatra Utara.

Bidura, I.G.N.G., I.B. Sudana, I.G. Mahardika, I.P. Suyadnya, I.G.L.Oka, and I.A.I. Aryani (2012). The Implementation of Saccharomyces spp.n-2 Isolate Tape (isolation from traditional yeast tape) for Improving Feed Quality and Performance of Male Bali Duckling. Agricultural Science Research Journal. http://www.resjournals.com/ARJ/Index.ht m. 2(9): 486-492.

Bidura I.G.N.G.,N.W.Siti \& I.B.G. Partama. (2019). Effect of probiotics, 
Saccharomyces spp.Kb-5 and $\mathrm{Kb}-8$, in Diets on Growth Performance and Cholesterol Levels in Ducks. South African Journal of Animal Science. 49 (2): 219-226.

Daud M, Fuadi Z, \& Sultana (2013). Penggunaan limbah kopi sebagai bahan penyusun ransum itik Peking dalam bentuk wafer ransum komplit. J Agripet. 13:36-42.

Daud, M. Yaman MA, \& Zulfan (2015). Penggunaan Hijauan Kangkung (Ipmoea aquatica) Fermentasi Probiotik dalam Ransum Terhadap Performans Itik Peking. Prosiding Seminar Nasional Teknologi Peternakan dan Veteriner. Jakarta, 8-9 Oktober 2015. Puslitbang Peternakan, Bogor: 479-486.

Daud, M. Mulyadi \& Z. Fuadi (2016). Persentase Karkas Itik Peking yang Diberi Pakan dalam Bentuk Wafer Ransum Komplit Mengandung Limbah Kopi. Jurnal Agripet. 16 (1): 62-68.

Daud M, Yaman MA, Latif H, \& Asril (2017). Penggunaan Tepung Keong Mas dan Suplementasi Probiotik dalam Ransum terhadap Performa Itik Peking. Prosiding Seminar Nasional Teknologi Peternakan dan Veteriner: 407-414.

Daud, M., Zulfan \& M.A. Yaman (2018). Subsitusi Kulit Pisang Fermentasi Dalam Ransum Komersial Terhadap Performan Itik Peking. Prodising Forum Komunikasi Perguruan Tinggi Pertanian Indonesia (FKPTPI) Universitas Syiah Kuala Banda Aceh: 849-856.

Matitaputty, P.R., R.R. Noor, P.S. Hardjosworo, \& C.H. Wijaya. (2011). Performa, persentase karkas dan nilai heterosis itik Alabio, Cihateup dan hasil persilangannya pada umur delapan minggu. Jurnal Ilmu Ternak dan Veteriner 16: 90-97.

Mudita I Made, I.G.L.Oka Cakra, I.Gede Mahardika \& I Nyoman S.Sutama (2019). Biokatalis Pakan Limbah Pertanian Berbasis Eksperimental.Fakultas Peternakan Universitas Udayana. Cetakan I. Swasta Nulus.
Nurhayati (2013). Penampilan Ayam Pedaging yang Mengkonsumsi Pakan MengandungTepung Kulit Nanas Disuplementasi dengan Yoghurt. Jurnal Agripet. 13(2): 15-20.

Nurhayati, N. \& Berliana (2014). Perubahan Kandungan Protein dan Serat Kasar Kulit Nanas yang Difermentasi dengan Plain Yoghurt. Jurnal Ilmiah Ilmu-Ilmu Peternakan. 17 (1):31-38.

Nunes, O.J., Bertechini, G.A., Debrito G.A.J., Fassani, J.E., Mesquitq, R.F., Makiyama, L., \& Meneghetti, C., (2012). Evaluation of the use of probiotic (Bacillus subtillis C-3102) as additive to improve performance in broiler chicken diets. Revista Brasileira de Zootecnia. 41(11) 2374-2378.

NRC (National Research Council) (1994). Nutrient Requirementof Poultry. National Academy Press, Washington, D.C.

Prasetyo, M.A., S. Kismiati \& R. Muryani (2017). Produksi Karkas Itik Peking Yang Diberi Pakan Kering Dan Basah Dengan Penambahan Probiotik. Prosiding Seminar Nasional Optimalisasi Teknologi dan Agribisnis Peternakan dalam Rangka Pemenuhan Protein Hewan Asal Ternak ISBN 978-602-1004-42-5: 313-318.

Soeparno (2015). Ilmu Nutrisi dan Gizi Daging. Gajah Mada University Press. Yogyakarta. Edisi Revisi Cetakan ke enam.

Sumadi, I.K. (2018). Nutrisi Ternak Babi. Penerbit Swata Nulus, Cetakan 1, ISBN 978-602-5742-22-4.

Sukirmansyah, Muhammad Daud \& Herawati Latif (2016). Evaluasi Produksi dan Persentase Karkas Itik Peking dengan Pemberian Pakan Fermentasi Probiotik. Jurnal Ilmiah Mahasiswa Pertanian Unsyiah, 1(1): 1-5.

Steel, R.G.D \& J.H. Torrie (2015). Prinsip Dan Prosedur Statistika. Penterjemah Bambang Sumantri. Gramedia Pustaka, Jakarta. 
Tanwiriah, W.,T. Widjastuti \& G. Darnida, (2018). Performa Pertumbuhan Itik Peking Jantan Pada Umur Panen Berbeda.

Prosiding Seminar Nasional.

Pengembangan Unggas Lokal Indonesia : 67-71. 